\title{
Study on improving interface bonding performance of magnesium potassium phosphate cement mortar
}

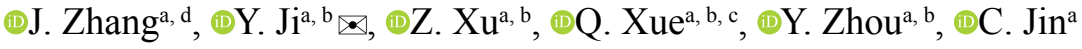 \\ a. Jiangsu Key Laboratory Environmental Impact and Structural Safety in Engineering, China University of Mining and Technology, \\ (Xuzhou, Jiangsu, China) \\ b. State Key Laboratory for Geomechanics and Deep Underground Engineering, China University of Mining and Technology, (Xuzhou, \\ Jiangsu, China) \\ c. Jiangsu Collaborative Innovation Center for Building Energy Saving and Construct Technology, (Xuzhou, Jiangsu, China) \\ d. School of Architecture Engineering, Xuzhou College of Industrial Technology, (Xuzhou, Jiangsu, China) \\ jysbh@126.com
}

Received 10 January 2021

Accepted 21 April 2021 Available

on line 17 August 2021

\begin{abstract}
To enhance the interfacial bonding performance between magnesium potassium phosphate cement (MKPC) repair mortar and matrix concrete, in this study, MKPC modified mortar was used as the repair material to splice long prismatic test pieces. The four-point bending test was used to determine the flexural bearing capacity of the long prism, and the influence of changing the interface conditions and the modifying the MKPC repair mortar on the improvement of the basic performance of the splicing component is investigated.The research results show that, when the matrix concrete section is in a natural state, applying silica-fume modified MKPC interface agents on the interface with a repair thickness of $3 \mathrm{~cm}$ can improve the interface bonding performance. Furthermore, the working performance and mechanical properties of the MKPC repair mortar modified using nickeliron slag and steel fibers have been significantly improved.
\end{abstract}

KEY WORDS: Blended cement; Adherence; Flexural strength; Interstitial zone; Mortar.

Citation/Citar como: Zhang, J.; Ji, Y.; Xu, Z.; Xue, Q.; Zhou, Y.; Jin, C. (2021) Study on improving interface bonding performance of magnesium potassium phosphate cement mortar. Mater. Construcc. 71 [343], e255. https://doi.org/10.3989/mc.2021.00421.

RESUMEN: Estudio sobre la mejora del rendimiento de la adherencia del mortero de cemento de fosfato de potasio y magnesio. Para mejorar el rendimiento de la adhesión entre el mortero de reparación de cemento de fosfato de magnesio y potasio (MKPC) y el hormigón matriz, se utilizó un mortero modificado con MKPC como material de reparación para unir piezas de ensayo prismáticas largas. Se utilizó el ensayo de flexión en cuatro puntos para determinar la capacidad de soporte a la flexión del prisma largo, y se investigó la influencia del cambio de las condiciones de la interfaz y la modificación del mortero de reparación MKPC en la mejora del rendimiento básico del componente de unión. Los resultados de la investigación muestran que, cuando la sección de hormigón matriz está en estado natural, la aplicación de agentes de interfaz MKPC modificados con humo de sílice en la interfaz con un espesor de reparación de $3 \mathrm{~cm}$ puede mejorar el rendimiento de unión de la interfaz. Además, el rendimiento de trabajo y las propiedades mecánicas del mortero de reparación MKPC modificado con escoria de níquel-hierro y fibras de acero mejora significativamente.

PALABRAS ClAVE: Cemento con adiciones; Adherencia; Resistencia a la flexión; Zona intersticial; Mortero.

Copyright: (C2021 CSIC. This is an open-access article distributed under the terms of the Creative Commons Attribution 4.0 International (CC BY 4.0) License. 


\section{INTRODUCTION}

Prefabricated concrete buildings are important to further industrialization, and have the advantages of improving quality, shortening construction periods, saving energy, reducing consumption and having cleaner production. For the large-scale assembly of precast concrete components, the splicing of nodes and components are crucial factors that affect the overall quality and manufacturing process. The splicing materials must work well with prefabricated components and complete processing in a relatively short period of time. Furthermore, the materials must have good construction operability for various specialized or complex prefabricated components (1). For precast-concrete industrialization, the splicing technology of its components has become crucial.

Existing splicing materials can be divided into organic and inorganic materials, according to their chemical composition. The strength of organic materials is advancing rapidly, which allows them to meet the requirements for the rapid construction of component splicing. Further, the bonding force with the original concrete is very strong, reaching the bearing capacity for splicing components. Therefore, organic materials have become the primary materials used for assembling concrete structures (2-4). However, organic splicing materials tend to age and have a short life, leading to serious safety hazards in terms of the long-term carrying capacity of spliced components. In contrast, inorganic materials do not have significant ageing problems, and can meet the basic requirements in terms of service life (5-7). The inorganic splicing materials used at present are primarily cement-based materials, which have low early strength and large shrinkage $(8,9)$. Cracks occur quite easily between cement-based materials and the underlying concrete matrix due to drying shrinkage, which necessitates a long curing time and can be used only to reach a certain intensity, seriously affecting the construction schedule and operating requirements for efficient component splicing. Therefore, the development of a new type of inorganic cementitious material with high early strength, strong bonding force with the matrix concrete, convenient construction and reasonable cost has become the focus of current research.

Magnesium potassium phosphate cement (MKPC) is an inorganic cementitious material with a K-struvite as the binding phase (10-12), formed by the dead-burnt magnesium oxide, soluble potassium dihydrogen phosphate salt, and an admixture in a certain proportion through an acid and alkali chemical reaction and physical action under acidic conditions (13-15). Qiao et al. studied the basic properties of MKPC mortar and its bonding performance with matrix concrete from different perspectives. Research has shown that the acid base component of MKPC neutralizes quickly in water, develops strength quickly and has high early strength - especially within an hour $(16,17)$. Further, MKPC slurry has a low water-binder ratio, low shrinkage rate and thermal expansion coefficient, good volume stability, high environment temperature adaptability, good compatibility with concrete and good durability (18, 19). Based on these advantages, this material has been widely used in highway and airstrip repair (20).

From the point of view of repair, the strength grade of the repairing material should not be lower than that of the mended concrete matrix. Because the strength grade of pavement slab concrete is generally not high, and it mainly bears vertical pressure, MKPC repair materials can easily meet the compressive strength requirements. Although vehicle loads may also lead to a vertical shear effect on the repair interface, in comparison to Portland cement, MKPC has strong adhesion and almost no volume shrinkage in the hardening process, which can ensure a reliable bond between the repair material and the matrix concrete in the road repair. However, when the stress of the pavement plate is different, it is difficult to avoid complex stress states such as tension, bending or buckling of the stitched artefacts, which requires the joining of fabricated structure materials that have high compressive strength, high bending strength and strong bonding strength of concrete with the matrix. Although MKPC has better cementitious properties, in comparison to organic splicing materials, its flexural strength and bonding strength with matrix concrete are still low, and do not meet the basic requirements for splicing components in terms of mechanical properties (21). Therefore, it is important to study the mechanical properties of MKPC repair mortar and its inter-facial bonding properties with matrix concrete to facilitate the application of MKPC mortar in the field of component splicing.

To enhance the mechanical properties of MKPC repair mortar and its inter-facial bonding with matrix concrete, in this paper - by adding nickel slag, silica fume and steel fibre to MKPC - the effect of modification of the potassium magnesium phosphate repair mortar on its basic properties was studied. The long prism splicing specimen was prepared by using MKPC modified mortar as the repair material, using the long prism four-point bending test to measure the bending bearing capacity, and analysing the effects of the thickness of the repairing layer, the interface morphology of the specimen to be repaired, the interfacial agent applied with silica fume, and the modification of nickel slag and steel fibre on the flexural capacity of the potassium phosphate cement mortar splice concrete prism.

\section{RAW MATERIALS AND TEST METHODS}

\subsection{Selection of raw materials}

\subsubsection{Magnesium oxide}

Magnesium oxide ( $\mathrm{MgO}$ ) was prepared by calcining natural magnesite ore in an electric furnace at a 
TABLE 1. The chemical composition and basic physical properties of $\mathrm{MgO}$ powders.

\begin{tabular}{|c|c|c|c|c|c|c|c|c|c|}
\hline \multirow{2}{*}{ raw material } & \multicolumn{6}{|c|}{ chemical constitution (wt.\%) } & \multirow{2}{*}{$\begin{array}{l}\text { average } \\
\text { grading } \\
(\mu \mathrm{m})\end{array}$} & \multirow{2}{*}{$\frac{\text { specific surface area }}{\left(\mathrm{m}^{2} \cdot \mathrm{kg}^{-1}\right)}$} & \multirow{2}{*}{$\begin{array}{l}\text { density } \\
\left(\mathrm{g} / \mathrm{cm}^{3}\right)\end{array}$} \\
\hline & $\mathrm{MgO}$ & $\mathrm{CaO}$ & $\mathrm{SiO}_{2}$ & $\mathrm{Fe}_{2} \mathrm{O}_{3}$ & $\mathrm{Al}_{2} \mathrm{O}_{3}$ & Ignition loss & & & \\
\hline $\mathrm{MgO}$ & 96.8 & 1.33 & 0.92 & 0.34 & 0.16 & 0.95 & 45.26 & 216 & 3.11 \\
\hline
\end{tabular}

temperature above $1500^{\circ} \mathrm{C}$, and then ground using an SM-500 test mill for $30 \mathrm{~min}$. The particle size range of $\mathrm{MgO}$ was $10-60 \mu \mathrm{m}$ (18). Table 1 shows its chemical composition and basic physical properties of $\mathrm{MgO}$ powders.

\subsubsection{Potassium dihydrogen phosphate}

Potassium dihydrogen phosphate $\left(\mathrm{KH}_{2} \mathrm{PO}_{4}\right)$ is a colourless or white rhombic crystal with lustre. It was prepared through a neutralization reaction of potassium hydroxide or potassium carbonate with thermal phosphoric acid. The relative density is 2.338 , the melting point is $252.6^{\circ} \mathrm{C}$, and the particle size range of $\mathrm{KH}_{2} \mathrm{PO}_{4}$ was $40-60$ mesh. The technical parameters are shown in Table 2 .

TABLE 2. The technical parameters of potassium dihydrogen phosphate.

\begin{tabular}{lll}
\hline Serial number & index & content(wt.\%) \\
\hline 1 & $\mathrm{KH}_{2} \mathrm{PO}_{4}$ & $\geq 98$ \\
\hline 2 & Moisture & $\leq 2.5$ \\
\hline 3 & $\mathrm{pH}$ & $4.3-4.7$ \\
\hline 4 & Water insoluble content & $\leq 0.2$ \\
\hline 5 & $\mathrm{Fe}$ & $\leq 0.003$ \\
\hline 6 & $\mathrm{~K}_{2} \mathrm{O}$ & $\geq 33.9$ \\
\hline 7 & $\mathrm{As}$ & $\leq 0.005$ \\
\hline 8 & $\mathrm{CI}$ & $\leq 0.20$ \\
\hline 9 & $\mathrm{~Pb}$ & $\leq 0.005$ \\
\hline
\end{tabular}

\subsubsection{Retarding admixture}

The retarding admixture is a mixture of borax, disodium hydrogen phosphate dodecahydrate and chlorides in a mass ratio of $1: 1.5: 1$, which can be used to retard the coagulation and improve the fluidity (Note that in case of causing durability problem, applying this kind of retarder to reinforced concrete should be very careful.). The main per- formance indexes of the borax used met the requirements of GB/T632-1993. Disodium hydrogen phosphate dodecahydrate is a colourless and transparent columnar crystal, insoluble in ethanol and easy to weather in dry air. The details are given in Table 3 and Table 4.

TABLE 4. Related indicators of sodium hydrogen phosphate.

\begin{tabular}{lll}
\hline $\begin{array}{l}\text { serial } \\
\text { number }\end{array}$ & index & content (wt.\%) \\
\hline 1 & $\mathrm{Na}$ & $\geq 99.0 \%$ \\
\hline 2 & clarity test & qualified \\
\hline 3 & $\mathrm{pH}$ & $\leq 9.1 \sim 9.4$ \\
\hline 4 & water insoluble & $\leq 0.005 \%$ \\
\hline 5 & chloride & $\leq 0.001 \%$ \\
\hline 6 & total nitrogen & $\leq 0.002 \%$ \\
\hline 7 & sulfate $\left(\mathrm{SO}_{4}\right)$ & $\leq 0.005 \%$ \\
\hline 8 & $\mathrm{~K}$ & $\leq 0.01 \%$ \\
\hline 9 & Fe & $\leq 0.0005 \%$ \\
\hline 10 & As & $\leq 0.0005 \%$ \\
\hline 11 & heavy metals (calculated as $\mathrm{Pb})$ & $\leq 0.0005 \%$ \\
\hline
\end{tabular}

\subsubsection{Nickel slag}

Nickel slag is a type of industrial waste residue produced during the reduction smelting of nickel by an electric furnace. Table 5 shows the chemical composition of this nickel slag. It can be seen from the table that the main components of the slag are $\mathrm{SiO}_{2}, \mathrm{MgO}$, and $\mathrm{FeO}$, which form part of the $\mathrm{FeO}-$ $\mathrm{MgO}-\mathrm{SiO}_{2}$ ternary slag system. The main mineral composition of nickel slag is $2 \mathrm{MgO} \cdot \mathrm{SiO}_{2}, \mathrm{FeO} \cdot \mathrm{SiO}_{2}$ and $\mathrm{MgO} \cdot \mathrm{SiO}_{2}$. Nickel slag powder is obtained by grinding the crushed nickel slag through a test mill for 15 minutes and then passing it through a 200mesh sieve. In this paper, ultrafine powder of nickel slag was used, the specific surface area of which was $450 \mathrm{~m}^{2} / \mathrm{kg}$.

TABLE 3. Compositions of borax.

\begin{tabular}{|c|c|c|c|c|c|c|c|c|}
\hline ingredient & borax & $\begin{array}{l}\text { hydrochloric acid } \\
\text { insolubles }\end{array}$ & Chloride(Cl) & Sulfate $\left(\mathrm{SO}_{4}\right)$ & Phosphate $\left(\mathrm{PO}_{4}\right)$ & $\mathrm{Ca}$ & $\mathrm{Cu}$ & $\mathrm{Fe}$ \\
\hline content (wt.\%) & $\geqq 99.5$ & $\leqq 0.005$ & $\leqq 0.002$ & $\leqq 0.01$ & $\leqq 0.001$ & $\leqq 0.005$ & $\leqq 0.001$ & $\leqq 0.0003$ \\
\hline
\end{tabular}


TABLE 5. Chemical compositions of additions.

\begin{tabular}{lllllllllll}
\hline \multirow{2}{*}{$\begin{array}{l}\text { addition } \\
\text { varieties }\end{array}$} & \multicolumn{2}{l}{ chemical constitution (wt.\%) } \\
\cline { 2 - 12 } & $\mathrm{SiO}_{2}$ & $\mathrm{Al}_{2} \mathrm{O} 3$ & $\mathrm{CaO}$ & $\mathrm{Fe}_{2} \mathrm{O}_{3}$ & $\mathrm{MgO}$ & $\mathrm{TiO}_{2}$ & $\mathrm{~K}_{2} \mathrm{O}$ & $\mathrm{NiO}$ & $\mathrm{SO}_{3}$ & $\mathrm{Na}_{2} \mathrm{O}$ \\
\hline $\mathrm{Ni}$ & 48.65 & 3.41 & 1.35 & 8.05 & 31.28 & 0.10 & 0.10 & 0.06 & - & - \\
$\mathrm{Si}$ & 92.40 & 0.80 & 1.53 & 1.50 & 0.28 & - & - & - & - & 1.30 \\
\hline
\end{tabular}

\subsubsection{Silica fume}

Silica fume is a greyish-white powder with a density of $1600-1700 \mathrm{~kg} / \mathrm{m}^{3}$. More than $80 \%$ of the silica fume particles are smaller than $1 \mu \mathrm{m}$, and the average particle size is $0.1-0.3 \mu \mathrm{m}$. Silica fume is a kind of ultrafine hollow spherical powder with a very large specific surface area (about 30-50 times greater than that of fly ash), reaching $20-28 \mathrm{~m}^{2} / \mathrm{g}$. The main component of silica fume is active $\mathrm{SiO}_{2}$, which exhibits a high pozzolanic effect and dissolves in water quickly, filling pores in the mortar, improving its density, and enhancing its strength. More details are given in Table 5.

\subsubsection{Fine aggregate}

The fine aggregate used in this study was ordinary natural river sand with an apparent density of $2.628 \mathrm{~g} / \mathrm{cm}^{3}$ and fineness modulus of 2.65; the size distribution of fine aggregate is shown in Table 6. It was classified as a medium sand with good grading and could be used after washing and drying.

TABLE 6. Size distribution of fine aggregate.

\begin{tabular}{llllll}
\hline particle size range/ & $0.160-$ & $0.315-$ & $0.63-$ & $1.25-$ & $2.5-$ \\
$\mathrm{mm}$ & 0.315 & 0.63 & 1.25 & 2.5 & 5.0 \\
\hline $\begin{array}{l}\text { natural river sand/ } \\
\text { wt. } \%\end{array}$ & 10.8 & 50.6 & 23.7 & 9.2 & 5.7 \\
\hline
\end{tabular}

\subsubsection{Steel fibre}

A copper-plated micro-filament steel fibre was used in this study. Its single-wire shape was linear. Table 7 shows its technical indexes.

TABLE 7. Physical and mechanical properties of steel fibre.

\begin{tabular}{lllllll}
\hline $\begin{array}{l}\text { length } \\
(\mathrm{mm})\end{array}$ & $\begin{array}{l}\text { diam- } \\
\text { eter } \\
(\mathrm{mm})\end{array}$ & type & $\begin{array}{l}\text { den- } \\
\text { sity } \\
(\mathrm{g} /\end{array}$ & $\begin{array}{l}\text { elas- } \\
\text { ticity } \\
\text { mod- } \\
\left.\mathrm{cm}^{3}\right)\end{array}$ & $\begin{array}{l}\text { tensile } \\
\text { strength } \\
(\mathrm{MPa})\end{array}$ & $\begin{array}{l}\text { Elon- } \\
\text { gation } \\
\text { at } \\
\text { break }\end{array}$ \\
& & & & & $\begin{array}{l}\mathrm{GPa}) \\
(\%)\end{array}$ \\
\hline 13 & 0.2 & $\begin{array}{l}\text { Round } \\
\text { straight }\end{array}$ & 7.80 & $>210$ & $>2850$ & $<4.00$ \\
& & & & & \\
\hline
\end{tabular}

\subsubsection{Concrete materials}

P. I 42.5 Portland cement, supplied by Xuzhou Zhong-lian Cement Corporation in China was used in this study, which conformed to the Chinese Na- tional Standard GB175 (equivalent to European CEM I 42.5). The specific gravity of the cement was $3100 \mathrm{~kg} / \mathrm{m}^{3}$, its mean size was $26.6 \mu \mathrm{m}$, and its specific surface area was $348 \mathrm{~m}^{2} / \mathrm{kg}$. Table 8 shows the chemical composition of Portland cement. Selection of fine aggregates as shown in section 1.1 (6) of this manuscript. Crushed limestone coarse aggregates with a maximum nominal size, saturated surface dry (SSD) specific gravity, and water absorption of $40 \mathrm{~mm}, 2780 \mathrm{~kg} / \mathrm{m}^{3}$, and $1.52 \%$, respectively are used.

TABLE 8. Chemical composition of Portland cement / (wt\%).

\begin{tabular}{lllllllll}
\hline $\mathrm{SiO}_{2}$ & $\mathrm{Al}_{2} \mathrm{O}_{3}$ & $\mathrm{Fe}_{2} \mathrm{O}_{3}$ & $\mathrm{CaO}$ & $\mathrm{MgO}$ & $\mathrm{Na}_{2} \mathrm{O}$ & $\mathrm{K}_{2} \mathrm{O}$ & $\mathrm{SO}_{3}$ & Loss \\
\hline 24.55 & 7.77 & 3.62 & 54.59 & 2.68 & 0.31 & 1.50 & 2.24 & 1.2 \\
\hline
\end{tabular}

\subsection{Specimen schemes}

Two specimens $(100 \mathrm{~mm} \times 100 \mathrm{~mm} \times 200 \mathrm{~mm})$, which were to be repaired, were bonded to form long prisms along the axial direction with the repair mortar. The effects of the properties of MKPC mortar (such as the thickness of the repair layer, interface morphology, interfacial agent and fibre modification of the repair mortar) on the bonding properties of the specimens were studied using four-point bending tests on the long prism.

\subsection{Specimen preparation}

\subsubsection{Specimens to be repaired}

The specimens to be repaired were C30 concrete specimens made from ordinary cement, and the concrete weight ratio was cement: water: sand: stone $=0.5: 1: 1.24: 2.52$. The specimens were classified into groups: A, B, C, D, E and F (with six pieces in each group); details are given in Table 9. In groups $\mathrm{A}$ and $\mathrm{B}$, the size of the specimens was $100 \times 100 \times 200 \mathrm{~mm}$; no treatment was done on the back end of specimens after mould removal, and the ends of specimens were unprocessed interface. In group $\mathrm{C}$, the size of the specimens was $100 \times$ $100 \times 200 \mathrm{~mm}$, and the cement mortar on the end surface of the test piece was immediately removed with a steel wire brush to expose the coarse aggregate, forming a rough bonding interface. In group $\mathrm{D}$, the specimens were in the form of poured long prisms with dimensions of $100 \times 100 \times 400 \mathrm{~mm}$; after 28 days of standard curing, the specimen was 
split equally, and two specimens - with sizes of 100 $\times 100 \times 200 \mathrm{~mm}$, to be repaired - were formed with a natural fracture bond interface at the fracture. In group E, the size of specimens was $100 \times 100 \times 200$ $\mathrm{mm}$; wood strips of different shapes were inserted at one end of the mould during moulding, and the wood plates were pulled out after the concrete reached a certain strength, so as to form a bonding interface with different depths reserved at the end of the specimen; in group $\mathrm{F}$, a matrix specimen was used, with a size of $100 \times 100 \times 400 \mathrm{~mm}$.

TABLE 9. Type of specimen and section indication.

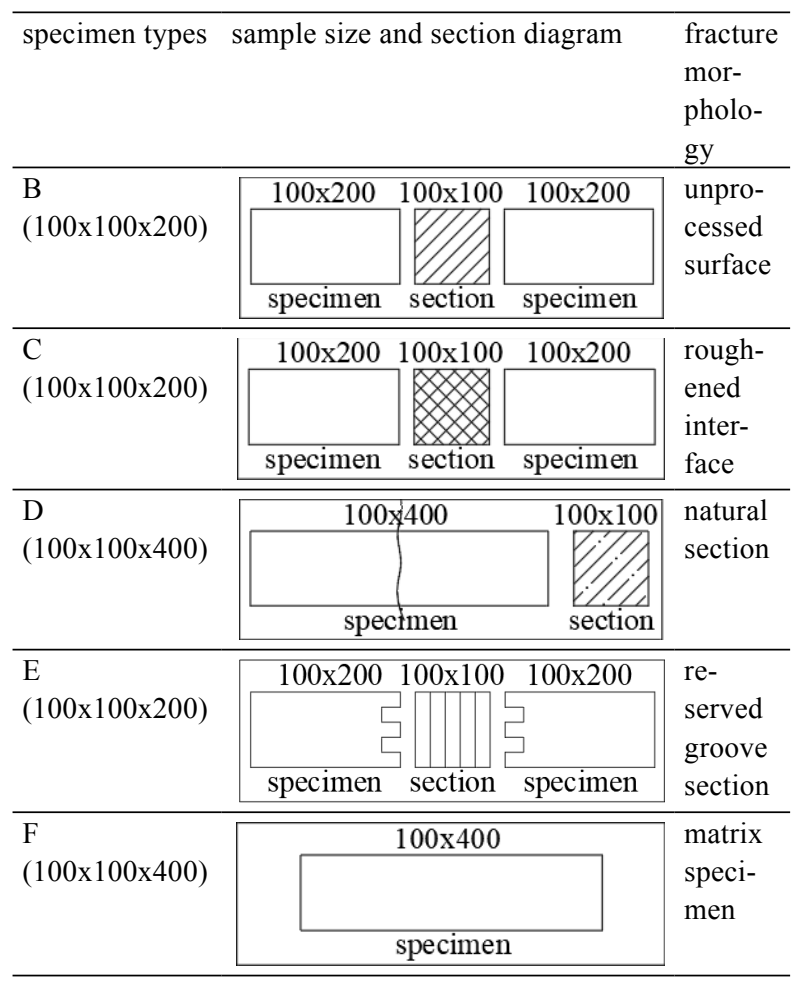

\subsubsection{MKPC mortar and its modified mortar}

MKPC mortar was used as the repair material, and nickel slag, silica fume, and steel fibre were used to modify MKPC. Subsequently, the nickel slag modified mortar (NMKPC), interfacial agent (SMKPC) and nickel-powder steel fibre composite modified mortar (FNMKPC) were prepared. Table 10 shows the mixed proportion of MKPC mortar and modified mortar.
The preparation process was as follows: first, the retarding admixture, $\mathrm{KH}_{2} \mathrm{PO}_{4}$, and water were poured into the mortar mixer according to the mass ratio of $1: 6.25: 3.13$, and the mixture was stirred slowly (rotation $140 \pm 5 \mathrm{rpm}$, revolution $62 \pm 5$ $\mathrm{rpm}$ ) for $1 \mathrm{~min}$ until it was fully dissolved. Second, magnesium oxide and its modifier (silica fume, nickel slag or steel fibre) were added and slowly stirred for $2 \mathrm{~min}$. Next, the mixture was stirred for $1 \mathrm{~min}$ (rotation $285 \pm 10 \mathrm{rpm}$, revolution $125 \pm$ $10 \mathrm{rpm}$ ) until it was fully mixed. Finally, the fine aggregate was added in a rapid mixing state and mixed until it was uniform.

\subsubsection{Repair and splicing of specimens}

The specimens were repaired and spliced after 28 days of standard curing. First, the two repair surfaces of the specimen to be repaired were put into an iron mould, and the distance between them was measured and adjusted by the scale, finally being fixed. Second, the repair material was poured in and the specimens were vibrated to ensure compactness. After vibration, the repair area of the specimen was cured through film mulching. The repair method of the specimen is shown in Figure 1. According to the specimen scheme, several groups of splicing specimens were fabricated, with three specimens in each group.

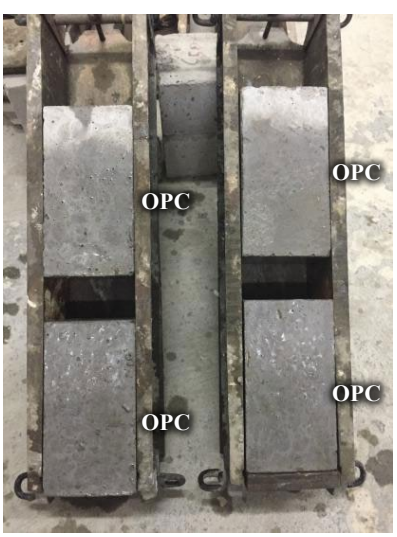

(a) Before specimen repair

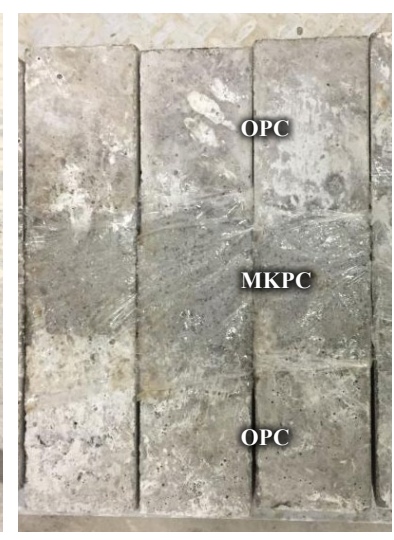

(b) After specimen repair
FIGURE 1. Repairing method of long prism specimen.

TABLE 10. Mix proportion of MKPC mortar $(\mathrm{g})$.

\begin{tabular}{llllllll}
\hline $\begin{array}{l}\text { ingredient } \\
\text { name }\end{array}$ & $\mathrm{MgO}$ & $\mathrm{KH} 2 \mathrm{PO} 4$ & $\begin{array}{l}\text { retardes } \\
\text { mixture }\end{array}$ & ad- & water & Ni & steel fibre \\
\hline MKPC & 450 & 300 & 48 & 150 & - & - & - \\
\hline SMKPC & 405 & 300 & 48 & 150 & 45 & - & - \\
\hline NMKPC & 405 & 300 & 48 & 150 & - & 45 & - \\
\hline FNMKPC & 405 & 300 & 48 & 150 & - & 45 & 30 \\
\hline
\end{tabular}




\subsection{Four-point bending tests}

Four-point bending tests were carried out on the repaired specimens after natural curing (temperature is $20 \pm 1^{\circ} \mathrm{C}$, with plastic-film curing) for three days. The test was carried out on a 5 t closed-loop hydraulic servo material testing machine. The loading mode was three-point loading and the loading rate was $0.5 \mathrm{~mm} / \mathrm{min}$. The loading mode is shown in Figure 2. The testing machine was equipped with a data acquisition and processing system, which can automatically collect and process the load and deformation data. According to the test results for data collection, the bending moment value of each group was read, and the average bending moment of each group (three pieces) was taken as the flexural capacity value for the group.

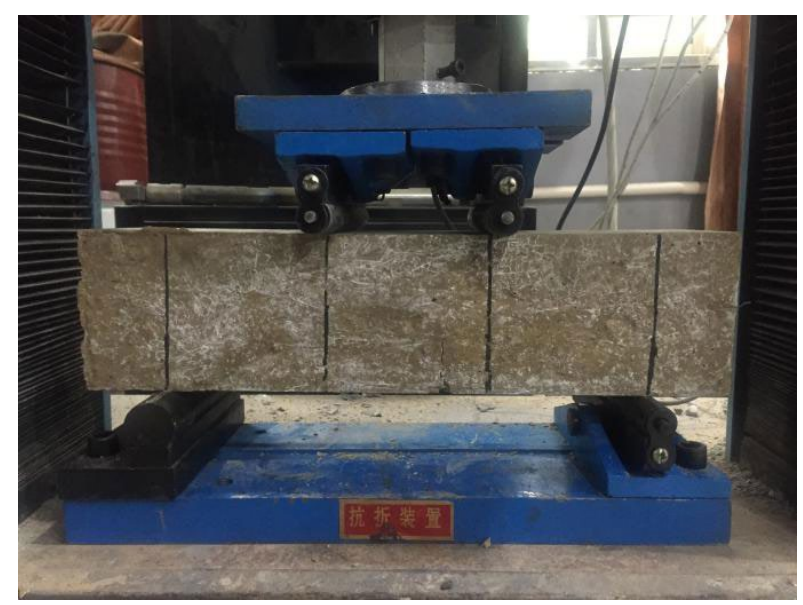

FIGURE 2. Loading method of long prism four-point bending test.

\subsection{Experimental research}

\subsubsection{Basic properties of MKPC mortar and its modified mortar}

MKPC mortar and its modified mortar were prepared according to the mix proportion given in section 1.3. The working performance and mechanical strength of MKPC mortar, nickel slag modified mortar and nickel-powder steel fibre composite modified mortar were determined according to the Test Method for the Fluidity of Cement Mortar GB/T 24192016 and Method of Testing Cements-Determination of Strength GB/T17671-2020. The strength test method of cement mortar is shown in Figure 3.

Analysis of compressive and flexural properties of $40 \mathrm{~mm} \times 40 \mathrm{~mm} \times 160 \mathrm{~mm}$ mortar specimens. Curing of mortar specimen, (1) After curing for 5 hours in natural environment, the mortar specimen was taken out and the specimen was demoulded. (2) The labeled specimen is placed horizontally in the curing chamber, and the specific curing method is: temperature $20 \pm 1^{\circ} \mathrm{C}$, relative humidity controlled at about $50 \%$.

\subsubsection{Effect of different interface factors on the flex- ural capacity of repaired specimens}

(1) The MKPC mortar splicing thicknesses are $1.00 \mathrm{~cm}, 2.00 \mathrm{~cm}, 3.00 \mathrm{~cm}, 4.00 \mathrm{~cm}, 5.00 \mathrm{~cm}$, and 6.00 $\mathrm{cm}$, when repairing and splicing the group A specimens. (2) The best thickness from (1) is then selected, and the test pieces of group B are repaired and spliced using nickel powder modified mortar. (3) Next, four

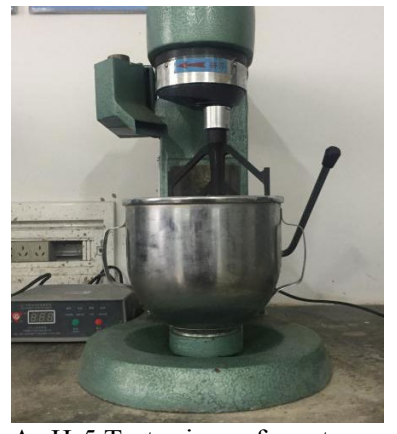

A. JJ-5 Test mixer of mortar

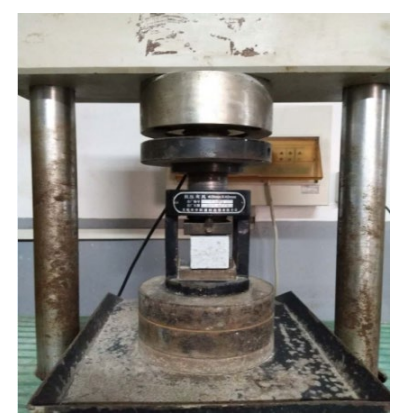

C. Compressive strength test

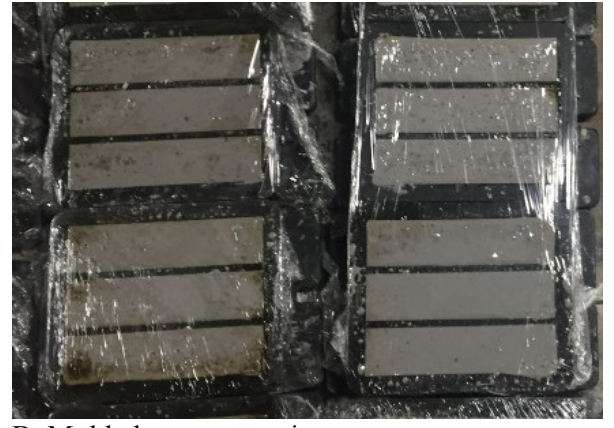

B. Molded mortar specimens

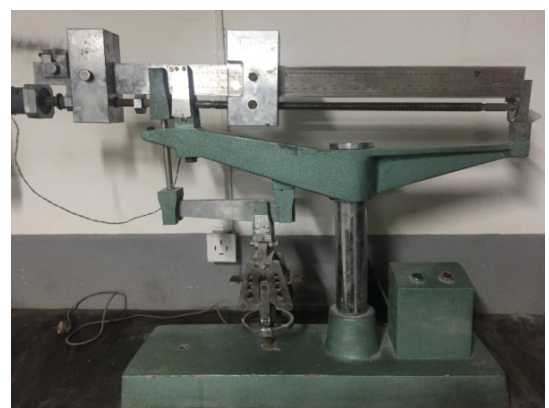

D. Flexural strength test

FIgURE 3. The strength test method of cement mortar. 
specimens with different interface morphology-from groups B, C, D, and E-are selected to be repaired and spliced with nickel powder modified mortar. (4) The best splicing interface morphology from step (3) is selected and 1-2 mm silica-fume modified mortar (interface agent) is smeared on the interface; then, nickel powder modified mortar is used to repair the splicing of the test piece. (5) On the basis of step (4), the steel fiber is added to the nickel powder modified mortar to continue to repair and splice the test piece. The above-mentioned steps are used to prepare the samples for measurement of the flexural bearing capacity of the test piece through four-point bending tests, observing the cross-sectional morphology of the test piece, and studying the effect of repair mortar thickness, modified mortar, interface morphology, and the interface agent on the flexural bearing capacity of the repaired sample.

\section{RESULTS AND DISCUSSION}

\subsection{Properties of MKPC mortar and its modified mortar}

\subsubsection{Working performance}

The mortar fluidities of MKPC, NMKPC, and FNMKPC are given in Table 11. It can be seen that the fluidity of MKPC mortar is $150 \mathrm{~mm}$, with high viscosity and relatively poor fluidity. The addition of nickel slag improves the fluidity of MKPC mortar - which increases from $150 \mathrm{~mm}$ to $180 \mathrm{~mm}$ - an increase of $20 \%$. This is because nickel-iron slag is a regular shaped vitreous body after grinding and has a smooth surface, such that friction with the particles is reduced and the fluidity is enhanced (22-24). The fluidity of nickel-powder steel fibre composite modified mortar is $170 \mathrm{~mm}$, which is slightly lower than that of nickel slag modified mortar, but its work performance is still greatly improved in comparison to MKPC mortar.

TABLE 11. Performance of cement mortar.

\begin{tabular}{llll}
\hline Mortar name & MKPC & NMKPC & FNMKPC \\
\hline fluidity $/ \mathrm{mm}$ & 150 & 180 & 170 \\
\hline
\end{tabular}

\subsubsection{Mechanical strength}

The mechanical strengths of MKPC mortar, nickel slag modified mortar and nickel-powder steel fibre composite modified mortar are shown in Table 12. It can be seen from Table 7 that the 3-day flexural strength and compressive strength of MKPC mortar are 6.15 $\mathrm{MPa}$ and 41.50 $\mathrm{MPa}$, respectively. The addition of nickel slag reduces the mechanical strength of MKPC mortar, and its flexural and compressive strength decreases by $5.70 \%$ and $4.82 \%$, respectively. With the addition of steel fibre, the flexural strength is increased by $81 \%$, while the compressive strength decreased by $1.45 \%$.

TABLE 12. Mechanical strength of repair mortar.

\begin{tabular}{lllll}
\hline Name & Day/d & MKPC & NMKPC & FNMKPC \\
\hline $\begin{array}{l}\text { flexural strength } \\
\text { / MPa }\end{array}$ & 3 & 6.15 & 5.80 & 11.15 \\
\cline { 2 - 5 } & 28 & 6.85 & 6.32 & 13.75 \\
\hline $\begin{array}{l}\text { compressive } \\
\text { strength / MPa }\end{array}$ & 3 & 41.50 & 39.50 & 40.90 \\
\cline { 2 - 5 } & 28 & 45.78 & 43.45 & 43.50 \\
\hline
\end{tabular}

Since nickel slag has a smooth surface, dense structure and high hardness, the fluidity of MKPC mortar increases and the interactions between $\mathrm{MgO}$ particles and aggregates is reduced (20-22). Further, the potential pozzolanic activity of nickel slag is low, the hydration reaction is relatively slow and the addition of nickel slag replaces part of the $\mathrm{MgO}$, which reduces the cementitious products generated by the hydration of $\mathrm{MgO}$ and $\mathrm{KH}_{2} \mathrm{PO}_{4}$, consequently decreasing the strength of MKPC mortar. The addition of steel fibre limits the lateral expansion of the component under compression, delays the failure process and the good adhesion between the steel fibre and matrix effectively inhibits the germination and expansion of matrix cracks $(23,24)$. As a result, the flexural strength of the matrix is enhanced.

\subsection{Effect of repair layer thickness on bonding performance}

\subsubsection{Influence of thickness of the repair layer on bending performance}

The effect of the repair layer thickness on the bending capacity is shown in Figure 4. It is clear that the flexural capacity of the matrix specimen is $16.23 \mathrm{kN}$. When the thickness of the repair layer is $1.00 \mathrm{~cm}$, the 3 -day flexural capacity of repairing the long prism is $4.57 \mathrm{kN}$, which is only $28.16 \%$ of that of the matrix specimen. With the increase in the thickness of the repair layer, the flexural capacity increases gradually. When the thickness of the repair layer is $3.00 \mathrm{~cm}$, its 3 -day bending capacity reaches the maximum value of $5.26 \mathrm{kN}$, which represents an increase of $32.41 \%$ in comparison to the matrix specimen. With a further increase in the thickness of the repair layer, the flexural capacity of the prism changes only slightly.

\subsubsection{Failure mode and cross-section morphology of splicing members}

The failure mode and section morphology of the splicing component are shown in Figure 5. Figure 5(a) shows that the failure of the specimen occurs at one side of the interface between the repair mortar and the cement matrix. In Figure 5(b), the fine aggregate distributed on the 


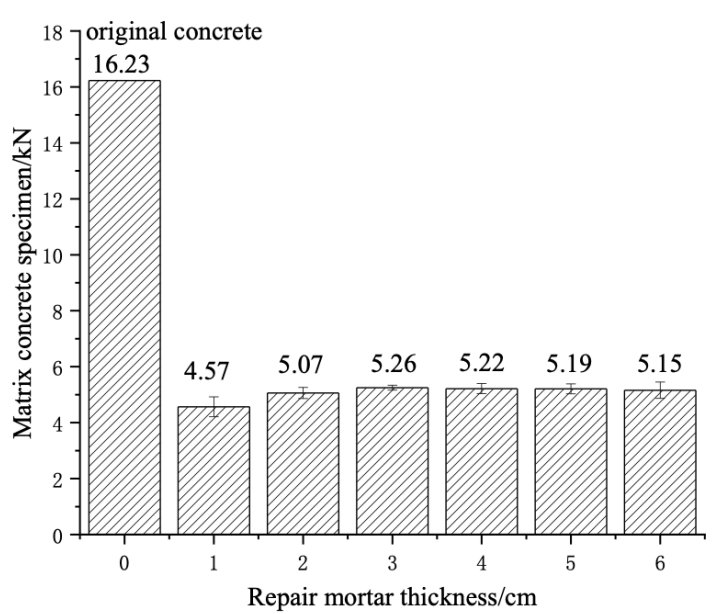

FiguRE 4. Effect of repaired mortar thickness on flexural capacity.

surface can be clearly seen on the repair mortar section, and some MKPC paste is attached to the cross-section of the cement matrix. In comparison to Figure 5(b), the MKPC paste adhered to the cement matrix section in Figure 5(c) is more uniform and continuous, and the interface is almost entirely covered with MKPC mortar.

According to the results of the influence of the thickness of the repair layer on the flexural capacity, the failure mode and section morphology of the spliced components, it can be concluded that when the thickness of the repair layer is less than $3 \mathrm{~cm}$, the MKPC mortar has high viscosity, poor fluidity and fast setting and hardening time, which is disadvanta- geous for construction applications (25-27); the repair mortar at the interface cannot fully infiltrate the bonding surface, resulting in discontinuous repair.

When the thickness of the repair layer is greater than or equal to $3 \mathrm{~cm}$, the working face for the injected vibration is relatively large, and operation is more convenient. The repair mortar at the interface can almost fully infiltrate the bonding surface, which increases the bonding strength between the repair mortar and the cement matrix (25). However, the thicker the bonding layer, the less sufficient the reaction between the repair mortar and the cement matrix, and the greater the internal stress caused by expansion and contraction at the bonding layer $(26,27)$. As a result, the bonding performance is affected at the bonding position.

Therefore, to ensure uniform continuity and cohesiveness of interface repair, a value of $3 \mathrm{~cm}$ can be used as the optimum thickness of the repair layer. However, it is important to further analyse and modify the performance of repair mortar to enhance its working performance.

\subsection{Effect of nickel slag modified MKPC mortar on bonding performance}

\subsubsection{Effect of nickel slag modified MKPC mortar on flexural strength}

The influence of nickel slag modified MKPC mortar on flexural capacity is shown in Table 13. The

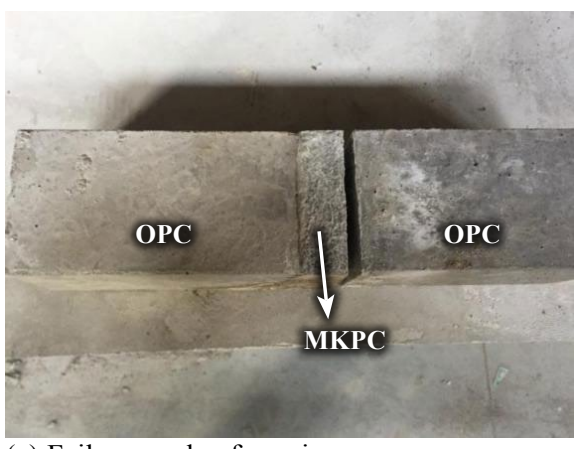

(a) Failure mode of specimen

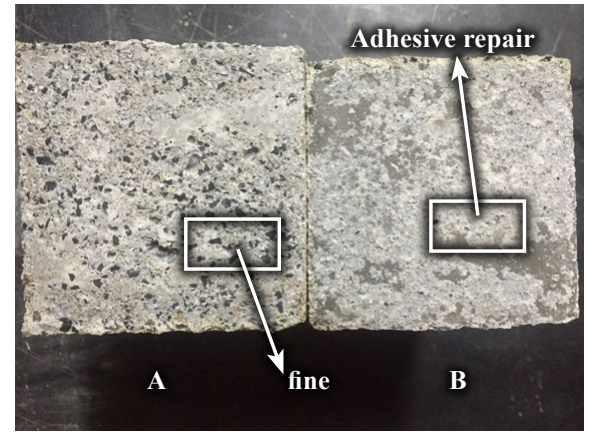

(b) The thickness of repair mortar is $2 \mathrm{~cm}$

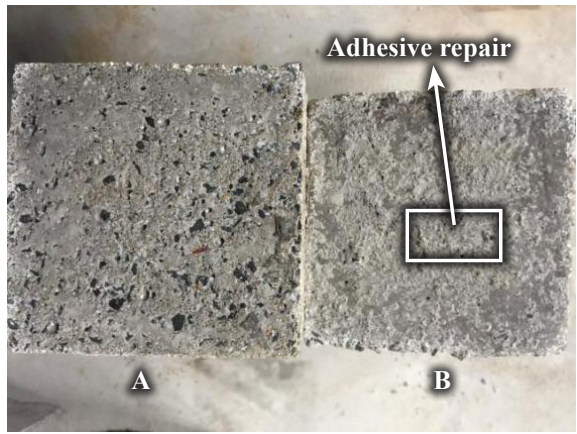

(c) The thickness of the repair mortar is $3 \mathrm{~cm}$

A: MKPC mortar repair surface; B: Bonding surface of matrix concrete

FIGURE 5. Failure mode and section diagram of the long prism. 
TABLE 13. Effect of nickel slag modification on flexural capacity.

\begin{tabular}{llll}
\hline Interface-type & Repair mortar variety & Repair mortar thickness $/ \mathrm{cm}$ & Flexural capacity $/ \mathrm{kN}$ \\
\hline unprocessed interface & MKPC & 3.00 & 5.26 \\
\hline unprocessed interface & MKPC $+10 \% \mathrm{Ni}$ & 3.00 & 6.27 \\
\hline
\end{tabular}

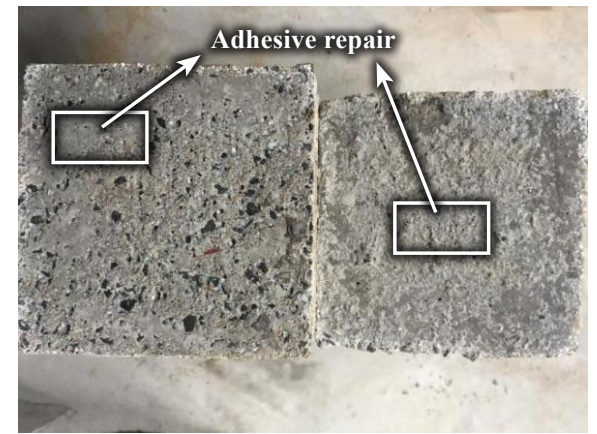

(a) MKPC

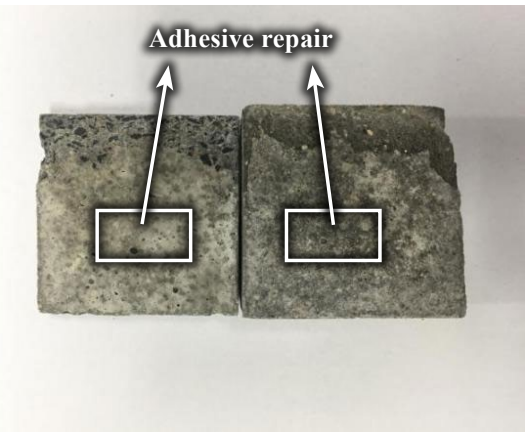

(b) $\mathrm{MKPC}+10 \% \mathrm{Ni}$

Figure 6. Cross section of modified nickel slag.

flexural capacity of MKPC mortar with 10\% nickel slag is $1 \mathrm{kN}$ higher than that of MKPC mortar alone. This is because nickel slag is glassy and its surface is smooth. The addition of nickel slag can improve the fluidity of MKPC mortar, which facilitates the subsequent injection and operation. Thus, the bonding area between the repair mortar and cement matrix is increased $(28,29)$. Further, the water requirement of the MKPC repair mortar with nickel slag is reduced, its setting time is longer and its working performance is improved, enhancing bonding performance (30).

\subsubsection{Failure mode and section morphology of nick- el slag modified MKPC mortar}

The failure mode and section morphology of the nickel slag modified MKPC mortar are shown in Figure 6. It is clear that the MKPC paste uniformly adheres to the damaged section of the cement matrix in Figure 6(b), and the MKPC paste is no longer uneven in thickness as the repair mortar on the fracture surface of the cement matrix in Figure 6(a). This is because nickel slag, as an addition, has the effect of reducing water content and plasticization. Nickel-slag can be used to improve the work performance of MKPC repair mortar, increase the bonding area with the cement matrix and improve the joint working performance of the repair mortar and cement matrix. However, the bonding strength between the repair mortar and cement matrix does not increase significantly. In other words, the bonding performance between the repair mortar and cement matrix should be increased by other means, such as changing the interface morphology.

\subsection{Effect of the interface morphology on flexural strength}

\subsubsection{Effects of different interface morphologies on flexural strength}

\section{(a) Roughened interface}

As shown in Figure 7, the flexural capacity of the roughened interface is $0.72 \mathrm{kN}$ higher than that of the unprocessed interface, indicating that the bonding strength between the interfaces is improved. This is because surface slurry and dust can be removed by chiselling untreated interfaces, such that concrete crushed stone is exposed and the roughness of the concrete surface increases. Then, the repair material penetrates into the uneven groove or gap in the substrate. After curing, a biting force is produced in the interface area, which rivets the cement matrix and enhances the bonding force.

(b) Natural section

It can be seen from Figure 7 that the flexural capacity of the natural section $(\mathrm{C})$ in the repair specimen is $7.27 \mathrm{kN}$, which represents the largest increase of all interface conditions. This is because the natural section is rougher than the roughened interface, and the concave-convex fracture surface is more obvious, which increases the effective contact area between the repair mortar and the old matrix specimen. After hydration of the MKPC mortar, the hydration product K-struvite has strong gelling characteristics, infiltrates into the pits of the natural section, and rivets more closely with the matrix concrete, such that the bonding performance of the two is maximized. Therefore, the greater the filling degree of the repair mortar for interface defects, the stronger the bonding performance.

(c) Reserved groove section

As shown in Figure 7, the flexural capacity of the cement matrix specimen with the reserved groove after repair increases with increases in groove depth. When the groove depth is $4 \mathrm{~cm}$, the flexural capacity is $7.46 \mathrm{kN}$. The bond strength of the two can be 
enhanced by using a toothed pattern connection. However, constructing the reserved groove section is labour-intensive, the injection of the repair mortar becomes difficult and the increase in bending bearing capacity is not significant. Therefore, this section form is not recommended.

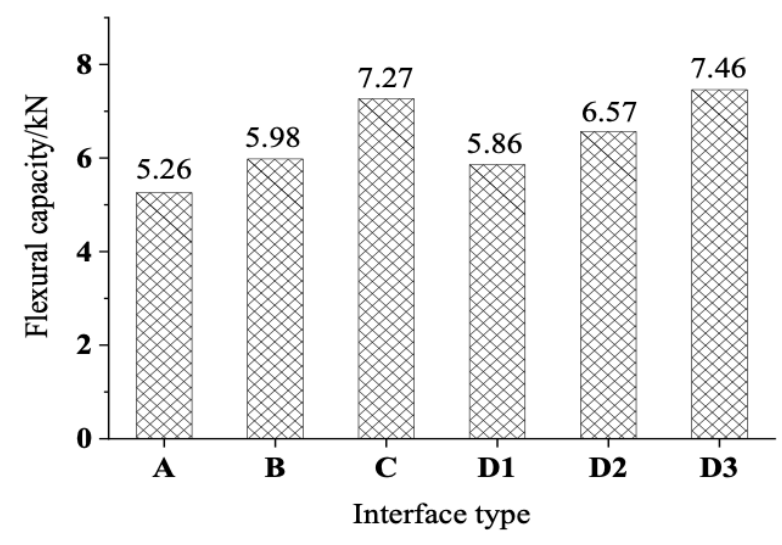

A-Unprocessed interface, B-Roughened interface, C-Natural section D1-The reserved groove depth is $2 \mathrm{~cm}$ D2-The reserved groove depth is $3 \mathrm{~cm}$ D3-The reserved groove depth is $4 \mathrm{~cm}$

FigURE 7. Effect of interface morphology on flexural capacity.

\subsubsection{Influence of interface morphology on the frac- ture surface}

The influence of interface morphology on the fracture surface can be seen in Figure 8. When the unprocessed interface is made rough, the repair mortar in the upper part of the section is pulled out from the hole, while the mortar in the lower part is broken along the repair surface. In the case of the natural section, coarse and fine aggregate become exposed on the surface, which can increase the mechanical tooth force and promote the Van der Waals force of the MKPC mortar $(21,22)$. In the case of the reserved groove, no matter how deep the groove is, the failure surface occurs at the outer edge of the groove, and the bonding effect of the groove is not obvious. According to the aforementioned results, it can be seen that the bonding properties of the natural cross-section are superior to those of other cross-section forms; only changing the interface morphology cannot change the weak position of the interface. Therefore, it is necessary to strengthen the interface on the basis of the natural section.

\subsection{Effect of the inter-facial agent on bonding properties}

\subsubsection{Effect of the interfacial agent on flexural strength}

The effects of the interfacial agents on flexural capacity can be seen in Table 14. The flexural capacity of nickel slag modified MKPC mortar coated with an interfacial agent is increased by $2.36 \mathrm{kN}$ in comparison to that without an interfacial agent, and its 3 -day flexural capacity is $10.83 \mathrm{kN}$. This is because silica fume has a small size and a better wetting effect on the concrete surface. It can effectively fill the gap on the surface and improve the homogeneity and compactness of the cement matrix. As a result, the structure of the interface zone is obviously improved and the bonding performance of the interface is enhanced, such that the nickel slag repair mortar is well bonded to the surface of the old matrix specimen (31-33).

\subsubsection{Effect of the interfacial agent on the failure position}

The effect of the interfacial agent on the failure position is shown in Figure 9. It can be seen from the figure that the cross-section position of the specimen coated with the interfacial agent is no longer at the bonding interface, but is transferred to the place of the repair mortar. The 3-day failure location of the repaired specimen is an oblique crack along the repaired mortar. The damage position of the specimen was still found to be at the repair mortar, and the mortar in the compression zone was crushed in 28 days. This is because silica fume is a kind of ultra-fine hollow spherical powder with a very large specific surface area. The incorporation of silica fume is conducive to filling the pore size of mortar, improving the interface performance of the cement matrix and enhancing the adhesion of the matrix interface, such that the bonding interface is no longer weak. However, the failure location still occurs within the repair area. If the strength of the repair mortar is enhanced, the absolute repair value of the repair material for the matrix can be realized. Therefore, the following section is aimed at enhancing the strength of the repair mortar.

\subsection{Effect of steel fibre modified mortar on bonding performance}

\subsubsection{Effect of steel fibre modified mortar on flexur- al capacity}

The influence of steel fibre modified mortar on flexural capacity is shown in Table 15. It is clear that, with the addition of steel fibre, the flexural capacity of specimen II is increased by about $3.33 \mathrm{kN}$ in comparison to that of specimen I; with all other conditions unchanged, when the curing age increases to 28 days, the flexural capacity of specimen III is increased by $2.73 \mathrm{kN}$, accounting for $98 \%$ of the flexural capacity of the matrix specimen. This is due 


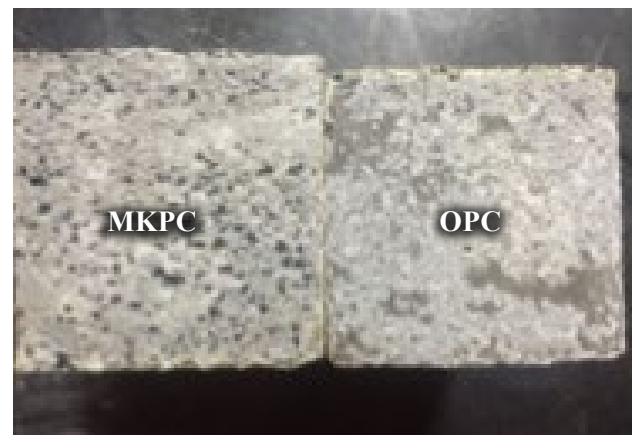

(a) Unprocessed interface

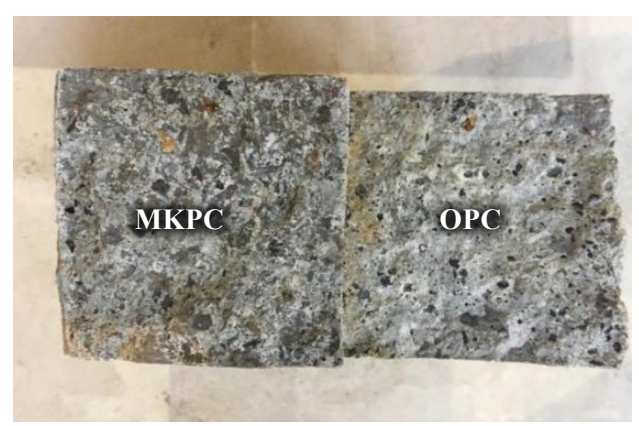

(c) Natural section

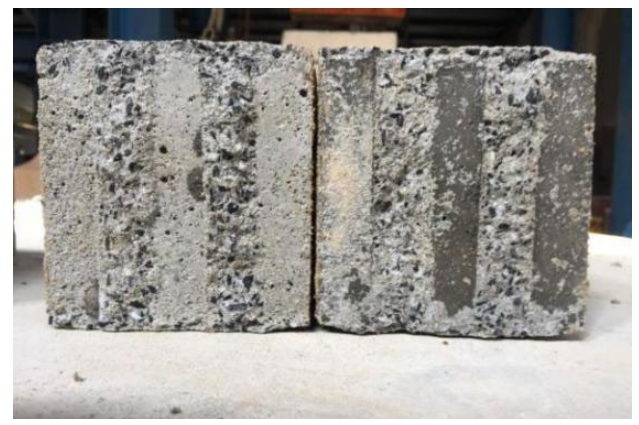

(e) The reserved groove is $3 \mathrm{~cm}$ deep

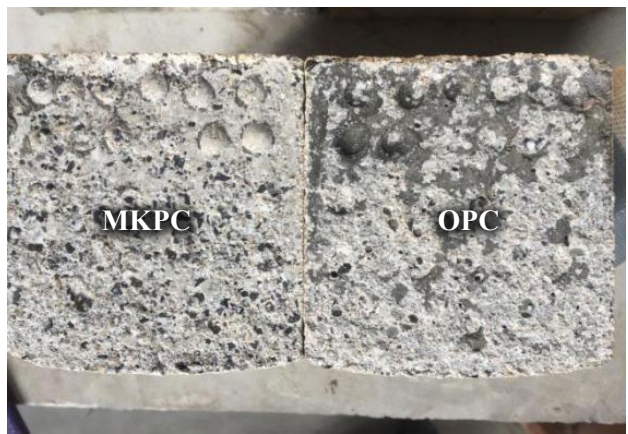

(b) Roughened interface

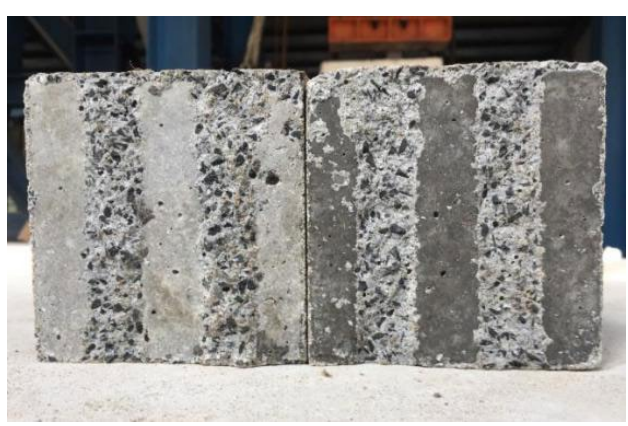

(d) The reserved groove depth is $2 \mathrm{~cm}$

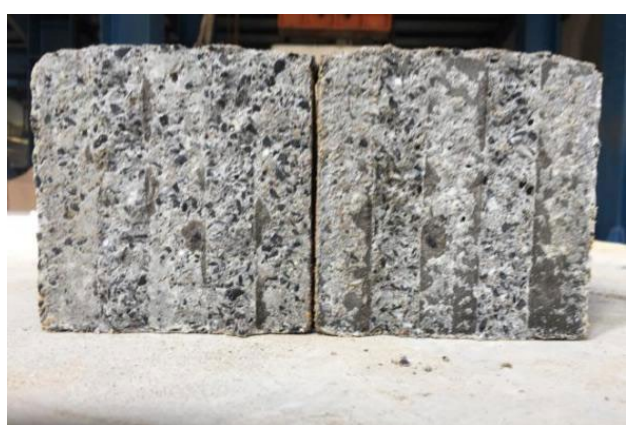

(f) The reserved groove is $4 \mathrm{~cm}$ deep

FiguRE 8. Effect of interface morphology on fracture section.

TABLE 14. Effect of interface agent on flexural capacity.

\begin{tabular}{llll}
\hline Interface-type & Repair mortar variety & Repair mortar thickness/cm & Flexural capacity/kN \\
\hline Natural section & MKPC & 3.00 & 7.26 \\
\hline Natural section & MKPC+10\%Ni & 3.00 & 8.47 \\
\hline Natural section + interfacial agent & MKPC+10\%Ni & 3.00 & 10.83 \\
\hline
\end{tabular}

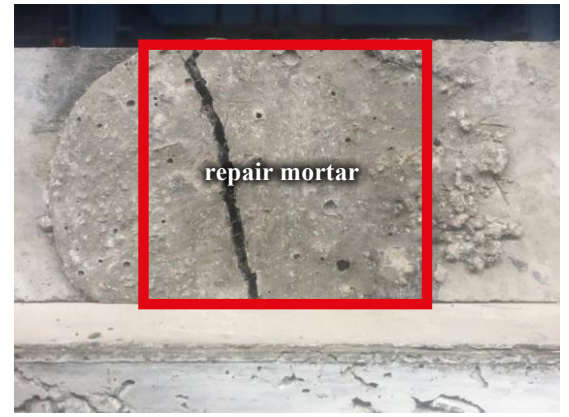

(a) Failure morphology of $3 \mathrm{~d}$ specimen

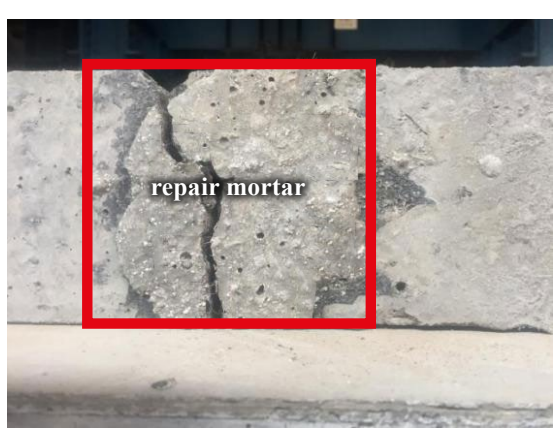

(b) Failure morphology of $28 \mathrm{~d}$ specimen

FigURE 9. Effects of interfacial agents on the location of damage. 
TABLE 15. Effect of fiber modification on flexural capacity.

\begin{tabular}{llllll}
\hline Test-piece & Interface-type & Repair mortar variety & The thickness of the slurry & Initial curing age & Flexural capacity kN \\
\hline I & $\begin{array}{l}\text { Natural section }+ \\
\text { interfacial agent }\end{array}$ & MKPC $+10 \% \mathrm{Ni}$ & $3 \mathrm{~cm}$ & Natural curing 3d & 10.83 \\
\hline II & $\begin{array}{l}\text { Natural section }+ \\
\text { interfacial agent }\end{array}$ & $\begin{array}{l}\text { MKPC }+10 \% \mathrm{Ni}+\text { steel } \\
\text { fibre }\end{array}$ & $3 \mathrm{~cm}$ & Natural curing 3d & 13.16 \\
\hline III & $\begin{array}{l}\text { Natural section }+ \\
\text { interfacial agent }\end{array}$ & $\begin{array}{l}\text { MKPC }+10 \% \mathrm{Ni}+\text { steel } \\
\text { fibre }\end{array}$ & $3 \mathrm{~cm}$ & Natural curing 28d & 15.89 \\
\hline
\end{tabular}
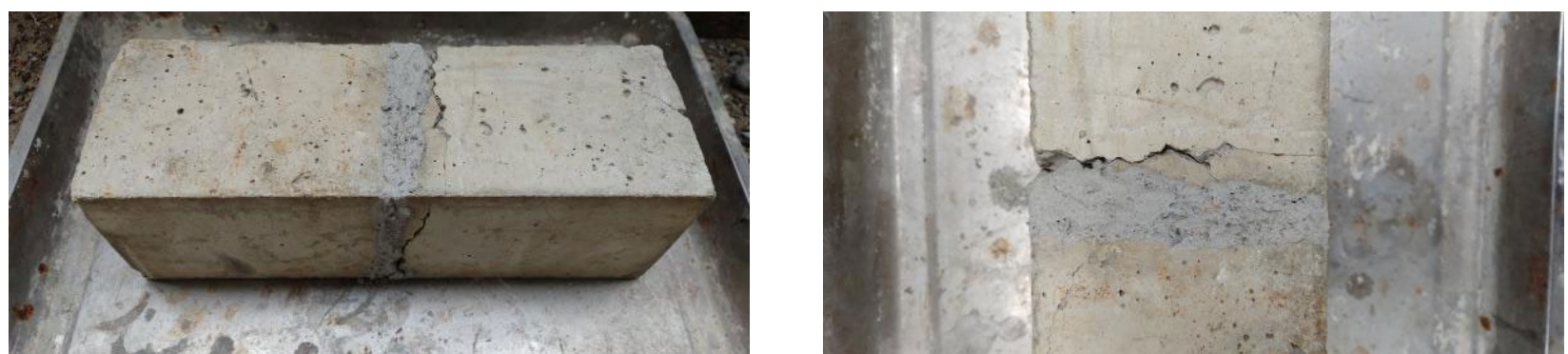

FIGURE 10. Effects of steel fiber modified mortar on the failure morphology of specimens.

to the strong tensile properties of steel fibre, which can effectively inhibit the generation and expansion of cracks in the repair mortar. Hence, the flexural strength of repair mortar is greatly improved, and its bearing capacity and toughness are increased.

\subsubsection{Effect of steel fibre modified mortar on the failure morphology of specimens}

The influence of steel fibre modified mortar on the failure morphology of specimens is shown in Figure 10. It can be seen from the figure that the fracture position of the repaired specimen occurs in the cement matrix. This indicates that the application area of repair mortar is no longer the weak position that leads to failure; the ultimate failure position changes owing to the enhancement of the flexural capacity of the repair mortar (34-36).

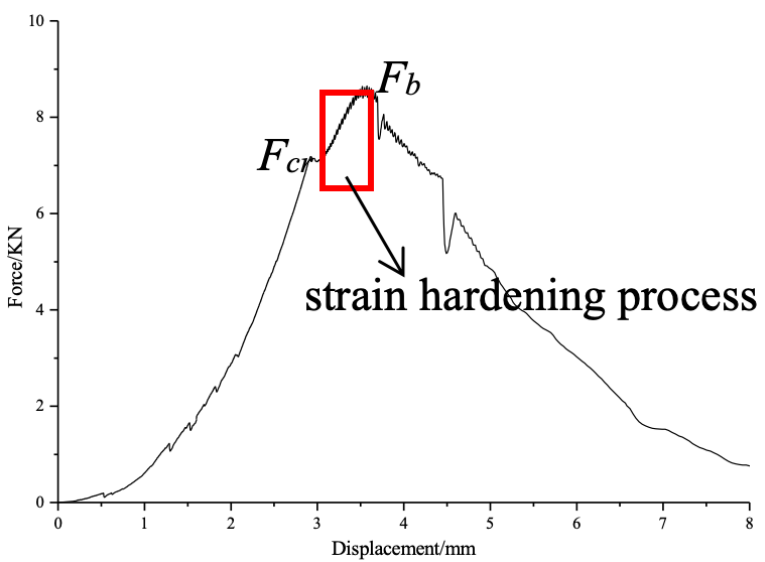

(a) Load-displacement curve (3d)

\subsubsection{Influence of steel fibre modified mortar on the load-displacement curve}

The effect of steel fibre modified mortar on the load-displacement curve is shown in Figure 11. It can be seen from the figure that when the load of the steel fibre modified MKPC mortar approaches the initial crack load, the specimen does not fail immediately, but experiences a certain strain hardening process. At this stage, the mechanical properties of steel fibre are fully exerted. The longer the stage, the better the effect of fibre connection, and the higher the toughness and energy absorption capacity of the composite. When the external load is applied, it is necessary to overcome the chemical binding force and friction force between the steel fibre and MKPC mortar. Therefore, the steel fibre cannot be pulled out easily, but will be in the stage of repeated load-

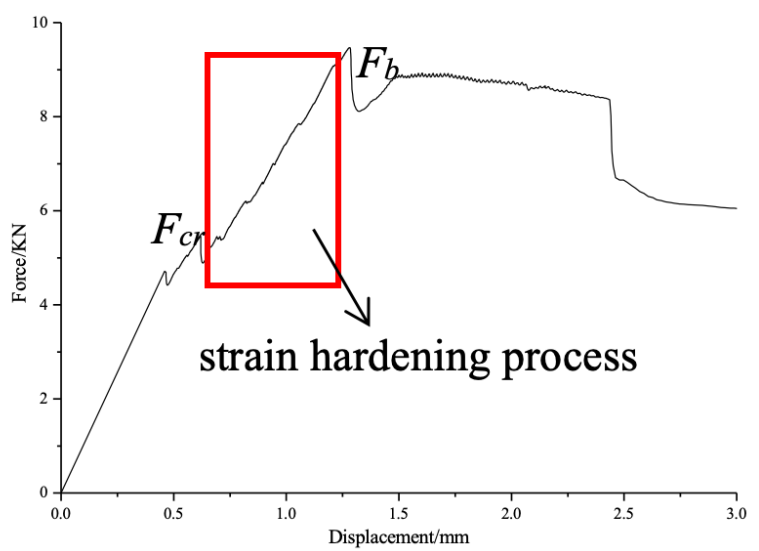

(b) Load-displacement curve (28d)

FIGURE 11. Force-displacement curve of four-point bending test. 


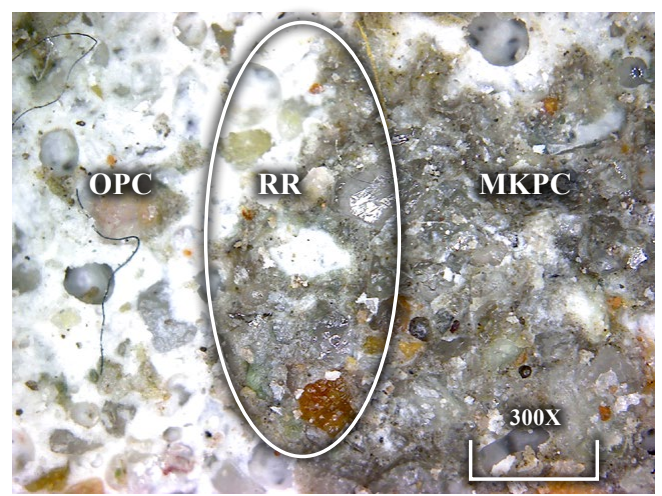

(a) 3-day

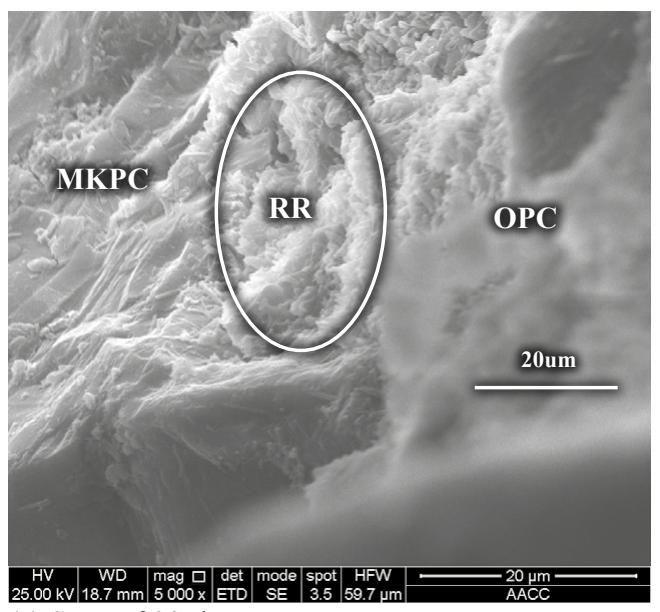

(c) SEM of 28-day

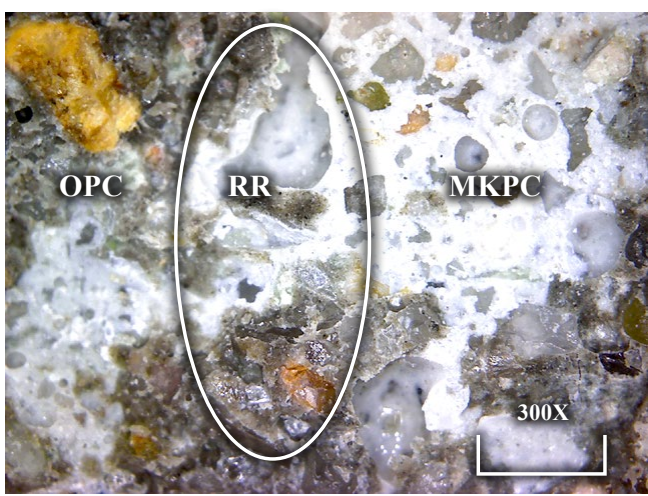

(b) 28-day

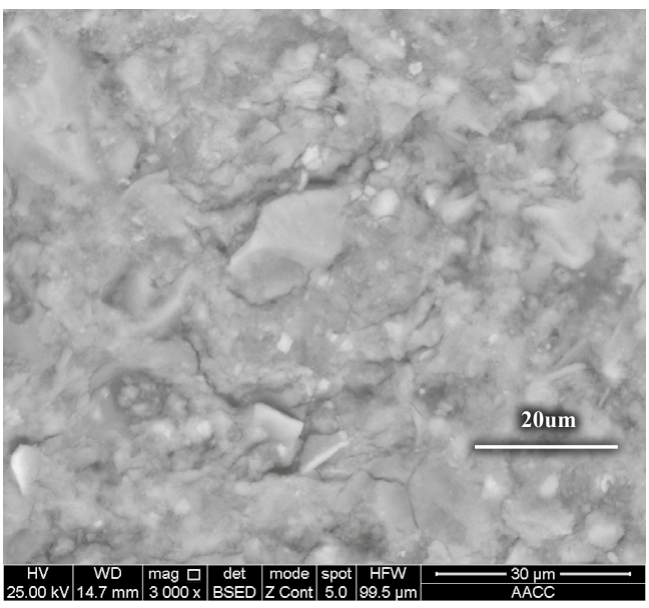

(d) Back-scattered electron diffraction of 28-day

FIGURE 12. Interface position connection morphology.

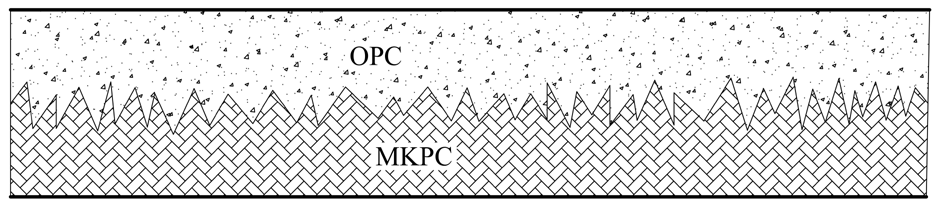

(a) Mechanical activation adhesion

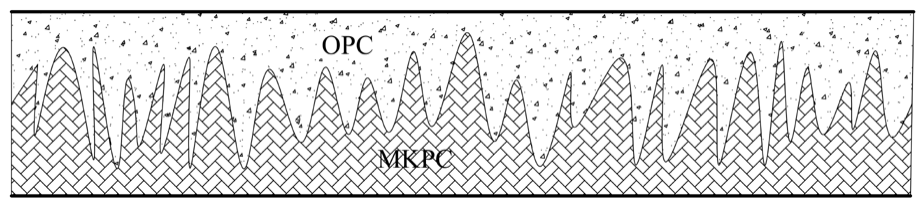

(b) Inter-diffusion

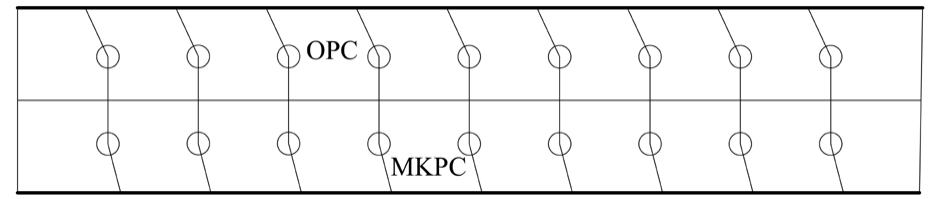

(c) Chemical bond combination

Figure 13. Type of Interface Bonding Force. 
ing and unloading. In the load-displacement curve, dense ripples are generated in the curve after the ultimate load is reached. The more stable this stage is, the more stable the formation and propagation of cracks are, and the smaller the width of the microcracks formed (37-40).

\subsection{Interface Mechanism Analysis and Transition Zone Model between MKPC and OPC}

The connection form of MKPC and OPC interface transition zone is shown in Figure 11. It can be seen from the figure that the hydration products of MKPC and OPC at the interface are intertwined, overlapped and penetrated, and the two are firmly bonded together.

The development process of interfacial adhesion between MKPC and OPC is divided into mechanical adhesion, mutual diffusion and chemical bond bonding, as shown in Figure 13.

Interface structure is divided into two areas: (1) Contact layer and permeable layer: the thickness is about $2-3 \mu \mathrm{m}$, which includes two kinds of material interface chemical reaction products, and pores and water film; (2) Enrichment layer: K-struvite enrichment, thickness is about $10-20 \mu \mathrm{m}$. Interface transition zone is given in Figure 14.

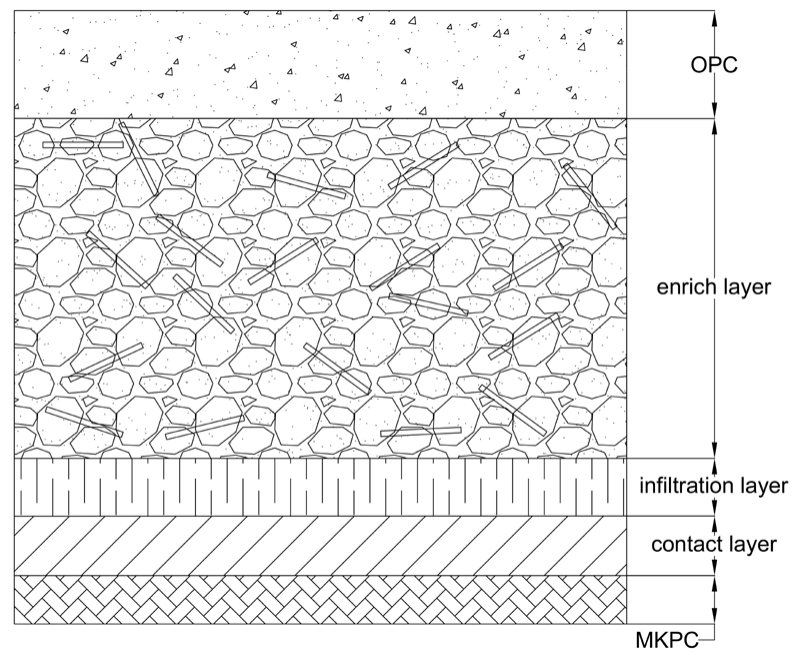

FIGURE 14. Interface transition zone.

\section{CONCLUSIONS}

The flexural strength of MKPC and the bond strength with the matrix concrete are still low, making it difficult to meet the basic requirements for splicing members in terms of mechanical properties. Therefore, it is necessary to improve the basic mechanical properties of the materials. Nickel-slag modification can effectively reduce the viscosity of MKPC and improve the quality of injection repair. Further, silica-fume modification can greatly improve the bonding strength of MKPC. The flexural strength of MKPC can be greatly improved by modification of steel fibre.

The interface morphology has a great influence on the bonding strength of the spliced interface; thus, it affects the flexural capacity of repaired specimens. The order in which the interface morphology affects the flexural capacity of the repaired specimens is as follows: fracture interface $>$ rough interface $>$ reserve slot interface $>$ unprocessed interface.

The optimum repair effect was obtained by applying a wollastonite modified interfacial agent on the fracture interface and using nickel-powder steel fibre composite modified MKPC mortar. The location of the damaged section was in the base concrete, which could reach the same flexural bearing capacity as that of the reference specimen.

\section{ACKNOWLEDGEMENTS}

The authors would like to express their appreciations to the Project supported by the National Natural Science Foundation of China (51972337). The research works belong to one part of the projects which are financially supported by NSFC.

\section{AUTHOR CONTRIBUTIONS:}

Conceptualization: Y. Zhou. Data curation: C. Jin. Formal analysis: J. Zhang. Funding acquisition: Y. Ji. Investigation: Q. Xue. Methodology: Z. Xu. Project administration: Y. Yi. Resources: Y. Yi. Software: Y. Yi. Supervision: Y. Yi. Validation: C. Ji. Roles/Writing, original draft: J. Zhang. Writing, review \& editing: J. Zhang, Y. Ji.

\section{REFERENCES}

1. Yuan, F; Pan, J; Xu, Z. (2013) A comparison of engineered cementitious composites versus normal concrete in beamcolumn joints under reversed cyclic loading. Mat. Struct. 46, 145-159. https://doi.org/10.1617/s11527-012-9890-6.

2. Gou, S; Ding, R; Fan, J.; Nie, X.; Zhang J. (2018) Seismic performance of a novel precast concrete beam-column connection using low-shrinkage engineered cementitious composites. Constr. Build. Mater. 192, 643-656. https://doi. org/10.1016/j.conbuildmat.2018.10.103.

3. Said, S.H.; Razak, H.A. (2016) Structural behavior of RC engineered cementitious composite (ECC) exterior beam-column joints under reversed cyclic loading. Constr. Build. Mater. 107, 226-234. https://doi.org/10.1016/j. conbuildmat.2016.01.001.

4. Qudah, S; Maalej, M. (2014) Application of engineered cementitious composites (ECC) in interior beam-column connections for enhanced seismic resistance. Engi. Struc. 69, 235-245. https://doi.org/10.1016/j.engstruct.2014.03.026.

5. Emmons, P.H.; Vaysburd, A.M. (1996) System concept in design and construction of durable concrete repairs. Constr. Build. Mater. 10 [1], 69-75. https://doi.org/10.1016/09500618(95)00065-8.

6. Popovics, S; Rajendran, N; Penko, M. (1987) Rapid hardening cements for repair of concrete. ACI Mater. J. 84 [1], 64-73.

7. Li, V.C.; Maalej, M. (1996) Toughening in cement based composites: Part I. Cement, mortar, and concrete. Cem. Conc. Comp. 18 [4], 223-237. https://doi.org/10.1016/09589465(95)00028-3. 
8. Mechtcherine, V. (2013) Novel cement-based composites for the strengthening and repair of concrete structures. Constr. Build Mater. 41, 365-373. https://doi.org/10.1016/j. conbuildmat.2012.11.117.

9. Ramakrishna, G; Sundararajan, T. (2005) Impact strength of a few natural fiber reinforced cement mortar slabs: A comparative study. Cem. Conc. Сomp. 27 [5], 547-553. https://doi.org/10.1016/j.cemconcomp.2004.09.006.

10. Wagh, A.S.; Singh, D; Jeong, S.Y. (1997) Chemically bonded phosphate ceramics for stabilization and solidification of mixed waste. Hazardous and radioactive waste treatment technologies handbook. 4 [2], 127-139.

11. Rao, A.J.; Pagilla, K.R.; Wagh, A.S. (2000) Stabilization and solidification of metal-laden wastes by compaction and magnesium phosphate-based binder. J. Air Waste Manag. Assoc. 50 [9], 1623-1631. https://doi.org/10.1080/10473289 .2000 .10464193 .

12. Zhang, S; Shi, H.S.; Huang, S.W. (2013) Dehydration characteristics of struvite-K pertaining to magnesium potassium phosphate cement system in non-isothermal condition. J. Ther. Ana. Calo. 111, 35-40. https://doi. org/10.1007/s10973-011-2170-9.

13. Suk-Pyo, K.; Jae-Hwan, K. (2015) Influence of Mixing Factors on the Early-Age Properties of Magnesium Potassium Phosphate Cement Mortar. J. Archi. Ins. Korea Struc. Cons. 31 [5], 61-68. https://doi.org/10.5659/JAIK SC.2015.31.5.61.

14. Chau, C.K.; Qiao, F; Li, Z. (2011) Microstructure of magnesium potassium phosphate cement. Constr. Build. Mater. 25 [6], 2911-2917. https://doi.org/10.1016/j. conbuildmat.2010.12.035.

15. Ding, Z; Dong, B.; Xing, F; Han, N.; Li, Z. (2012) Cementing mechanism of potassium phosphate based magnesium phosphate cement. Ceram. Int. 38 [8], 6281-6288. https://doi. org/10.1016/j.ceramint.2012.04.083.

16. Ma, H.; Xu, B.; Li, Z. (2014) Magnesium potassium phosphate cement paste: Degree of reaction; porosity and pore structure. Cem. Concr. Res. 65, 96-104. https://doi. org/10.1016/j.cemconres.2014.07.012.

17. Ma, H.; Xu, B.; Liu, J; Pei, H.; Li, Z. (2014) Effects of water content, magnesia-to-phosphate molar ratio and age on pore structure, strength and permeability of magnesium potassium phosphate cement paste. Mater. Design. 64, 497-502. https:// doi.org/10.1016/j.matdes.2014.07.073.

18. Mestres, G; Ginebra, M.P. (2011) Novel magnesium phosphate cements with high early strength and antibacterial properties. Acta Biomater. 7 [4], 1853-1861. https://doi. org/10.1016/j.actbio.2010.12.008.

19. Li, Y; Shi, T; Chen, B. (2015) Performance of magnesium phosphate cement at elevated temperatures. Constr. Build. Mater. 91, 126-132. https://doi.org/10.1016/j. conbuildmat.2015.05.055.

20. Xing, S.; Wu, C. (2018) Preparation of magnesium phosphate cement and application in concrete repair. MATEC Web Conf. 142, 01012. https://doi.org/10.1051/ matecconf/201814202007.

21. Yang, Q.; Zhu, B.; Wu, X. (2000) Characteristics and durability test of magnesium phosphate cement-based material for rapid repair of concrete. Mater. Struc. 33, 229234. https://doi.org/10.1007/BF02479332.

22. Júlio, E.N.B.S.; Branco, F.A.B.; Silva, V.D. (2004) Concreteto-concrete bond strength: influence of the roughness of the substrate surface. Constr. Build. Mater. 18 [9], 675-681. https://doi.org/10.1016/j.conbuildmat 2004.04.023.

23. Mu, B.; Meyer, C.; Shimanovich, S. (2002) Improving the interface bond between fiber mesh and cementitious matrix. Cem. Conc. Res. 32 [5], 783-787. https://doi.org/10.1016/ S0008-8846(02)00715-9.

24. Martinola, G.; Meda, A.; Plizzari, G.A.; Rinaldi, Z. (2010) Strengthening and repair of RC beams with fiber reinforced concrete. Cem. Conc. Comp. 32 [9], 731-739. https://doi. org/10.1016/j.cemconcomp.2010.07.001.

25. Hongtao, W; Juhui, C. (2007) Study on the setting time of magnesia-phosphate cement. J. Logis. Engin. Univ. 23 [2], 8487.

26. Qian, J.; You, C; Wang, Q.; Wang, H.; Jia, X. (2014) A method for assessing bond performance of cement-based repair materials. Constr. Build. Mater. 68, 307-313. https:// doi.org/10.1016/j.conbuildmat.2014.06.048.

27. Momayez, A; Ehsani, M.R.; Ramezanianpour, A.A. (2005) Comparison of methods for evaluating bond strength between substrate concrete and repair materials. Cem. Conc. Rese. 35 [4], 748-757. https://doi.org/10.1016/j. cemconres.2004.05.027.

28. Saha, A.K.; Sarker, P.K. (2016) Expansion due to alkalisilica reaction of ferronickel slag fine aggregate in OPC and blended cement mortars. Constr. Build. Mater. 123, 135-142. https://doi.org/10.1016/j.conbuildmat.2016.06.144

29. Katsiotis, N.S.; Tsakiridis, P.E.; Velissariou, D.; Katsiotis, M.S.; Alhassan, S.M.; Beazi, M. (2015) Utilization of ferronickel slag as additive in Portland cement: A Hydration Leaching Study. Waste Bio. Valor. 6, 177-189. https://doi. org/10.1007/s12649-015-9346-7.

30. Lemonis, N; Tsakiridis, P.E.; Katsiotis, N.S.; Antiohosc, S.; Papageorgiouc, D.; Katsiotisd, M.S.; Beazi-Katsiotia, M. (2015) Hydration study of ternary blended cements containing ferronickel slag and natural pozzolan. Constr Build. Mater. 81, 130-139. https://doi.org/10.1016/j. conbuildmat.2015.02.046

31. Güneyisi, E.; Gesoğlu, M.; Karaoğlu, S.; Mermerdaş, K. (2012) Strength, permeability and shrinkage cracking of silica fume and metakaolin concretes. Constr Build. Mater. 34, 120-130. https://doi.org/10.1016/j.conbuildmat.2012.02.017

32. Nochaiya, T.; Wongkeo, W.; Chaipanich, A. (2010) Utilization of fly ash with silica fume and properties of Portland cementfly ash-silica fume concrete. Fuel. 89 [3], 768-774. https:// doi.org/10.1016/j.fuel.2009.10.003.

33. Nili, M; Afroughsabet, V. (2010) Combined effect of silica fume and steel fibers on the impact resistance and mechanical properties of concrete. Int. J. Impact Engin. 37 [8], 879-886. https://doi.org/10.1016/j.ijimpeng.2010.03.004.

34. Holschemacher, K; Mueller, T; Ribakov, Y. (2010) Effect of steel fibres on mechanical properties of high-strength concrete. Mat. Design. 31 [5], 2604-2615. https://doi. org/10.1016/j.matdes.2009.11.025.

35. Xu, B.W.; Shi, H.S. (2009) Correlations among mechanical properties of steel fiber reinforced concrete. Constr. Build. Mater. 23 [12], 3468-3474. https://doi.org/10.1016/j. conbuildmat.2009.08.017.

36. Zhang, S.; Zhang, C.; Liao, L. (2019) Investigation on the relationship between the steel fibre distribution and the postcracking behaviour of SFRC. Constr. Build. Mater. 200, 539550. https://doi.org/10.1016/j.conbuildmat.2018.12.081.

37. Sirisha, K.; Rambabu, T.; Shankar, Y.R.; Ravikumar, P. (2014) Validity of bond strength tests: A critical review: Part I. J. Conserv. Dent. 17 [4], 305-311. https://doi. org/10.4103/0972-0707.136340.

38. Zhandarov, S.F.; Mäder, E.; Yurkevich, O.R. (2002) Indirect estimation of fiber/polymer bond strength and interfacial friction from maximum load values recorded in the microbond and pull-out tests. Part I: Local bond strength. J. Adhes. Sci. Technol. 16 [9], 1171-1200. https://doi. org/10.1163/156856102320256837.

39. Zhandarov, S.; Mäder, E. (2016) Determining the interfacial toughness from force-displacement curves in the pullout and microbond tests using the alternative method. Int. J. Adhes. Adhes. 65, 11-18. https://doi.org/10.1016/j. ijadhadh.2015.10.020

40. Ahmed, S.F.U.; Mihashi, H. (2007) A review on durability properties of strain hardening fibre reinforced cementitious composites (SHFRCC). Cem. Conc. Comp. 29 [5], 365-376. https://doi.org/10.1016/j.cemconcomp.2006.12.014. 